\title{
SENSORY NERVE CONDUCTION VELOCITY IN SUBJECTS WITH IRON-DEFICIENCY ANAEMIA
}

\author{
Subramaniyan Kumarasamy1, Anandhalakshmi Swaminathan², Harika Gorla3 ${ }^{3}$, Sundaravadivelu Velayutham ${ }^{4}$ \\ ${ }^{1}$ Associate Professor, Department of Medicine, SRM Medical College Hospital and Research Centre, SRM University, Kattankulathur. \\ 2Professor, Department of Physiology, SRM Medical College Hospital and Research Centre, SRM University, Kattankulathur. \\ 3Student, Department of Pharmacy Practice, SRM College of Pharmacy, SRM University, Kattankulathur. \\ ${ }_{4}^{4}$ Professor and Head, Department of Medicine, SRM Medical College Hospital and Research Centre, SRM University, Kattankulathur.
}

\section{ABSTRACT}

\section{BACKGROUND}

The predominant cause of anaemia in the general population is iron-deficiency anaemia, but there are little data about the peripheral nerve sensory function in subjects with iron-deficiency anaemia.

\section{AIM}

We aimed to investigate the effects of iron-deficiency anaemia on peripheral sensory nerve function.

\section{MATERIALS AND METHODS}

Our cross-sectional case-control study includes 40 individuals with iron-deficiency anaemia in the age range of 20 to 50 years from the Department of Medicine, SRM Medical College, and 30 age and sex matched subjects without anaemia as the control group. The patients or controls with the history of diabetes mellitus, neuromuscular, metabolic, vasculitic, or rheumatologic diseases or those taking medications that may alter central or peripheral nerve function were excluded from the study. Standard electrodiagnostic methods were used to study the sensory parameters like Sensory Nerve Conduction Velocity (SNCV) from Median, Ulnar, and Sural nerves from both the sides. Values from patients were compared with those of controls by unpaired student's t-test.

\section{RESULTS}

The observations revealed significant reduction in SNCV in the peripheral nerves in iron-deficiency anaemia.

\section{CONCLUSION}

The results indicated that there is alteration in sensory nerve conduction in iron-deficiency anaemia. This might be due to various functional and structural changes in peripheral nerves associated with iron deficiency.

\section{KEYWORDS}

Iron Deficiency Anaemia, Peripheral Neuropathy, Sensory Nerve Conduction.

HOW TO CITE THIS ARTICLE: Kumarasamy S, Swaminathan A, Gorla H, et al. Sensory nerve conduction velocity in subjects with iron-deficiency anaemia. J. Evolution Med. Dent. Sci. 2016;5(68):4879-4881, DOI: 10.14260/jemds/2016/1109

\section{INTRODUCTION}

Anaemia is defined as a decrease in the concentration of circulating red blood cells or in the haemoglobin concentration and concomitant impaired capacity to transport oxygen.[1]

Iron deficiency is the most prevalent nutritional deficiency and the most common cause of anaemia. In iron deficiency, the red blood cells become small (microcytic) and contains less haemoglobin (hypochromic) and thus the capacity of the blood to deliver oxygen to body cells and tissues is reduced. Irondeficiency anaemia adversely affects the cognitive performance, behaviour, physical growth, immune status, physical capacity, and work performance of individuals. ${ }^{[2]}$

Iron is very essential for proper development and functioning of the nervous system. Various studies had found developmental delays in iron-deficient infants.[3,4]

Financial or Other, Competing Interest: None.

Submission 16-07-2016, Peer Review 09-08-2016,

Acceptance 16-08-2016, Published 24-08-2016.

Corresponding Author:

Dr. Anandhalakshmi Swaminathan,

Professor,

Department of Physiology,

SRM Medical College Hospital and Research Centre,

SRM University, Kattankulathur,

Tamilnadu, India.

E-mail: dranandhalakshmismd@gmail.com

DOI: $10.14260 /$ jemds/2016/1109
In iron deficiency, the peripheral nerve function maybe impaired. There are only a few studies available regarding the peripheral nerve involvement in iron-deficiency anaemia, which is one of the most common health problems. So, we aimed to evaluate the sensory nerve conduction velocity in iron-deficiency anaemia.

\section{METHODOLOGY}

After ensuring that there were no history of cardiac, renal and hepatic illness, any acute illness, diabetes mellitus, alcohol addiction, leprosy, neuromuscular disorders, drug-induced neuropathy, family history of neuropathy, malignancy, HIV, myopathy and history of recent blood transfusion, and treatment for anaemia, etc., we enrolled 40 subjects diagnosed with iron-deficiency anaemia (group 1) attending the anaemia clinic and Medicine Department at SRM Medical College Hospital and Research Centre and 30 subjects without anaemia (group 2) as controls. All were in the age group of 20 to 50 years.

This cross-sectional case-control study was approved by the institutional ethical committee. The procedure was clearly explained to the subjects recruited for study and written informed consent was obtained from the subjects. Subject's brief clinical history, personal history, family history was taken and anthropometric data (age, height, and weight) and vital signs were recorded. Thorough clinical examination was 
done. Nerve conduction study was performed using the Neurostim machine manufactured by Medicaid systems. Three 1-cm disc surface electrodes were placed after applying jelly to reduce resistance in air between electrode and the skin surface. The temperature of the examination room was maintained at $25-28^{\circ} \mathrm{C}$. The subject was taken to the room, rested for a while so as to decrease the skin temperature to the recommended level of $32-34^{\circ} \mathrm{C}$. Thereafter, the nerve conduction study procedure was carried out with the subject lying in the supine position. The Sensory Nerve Conduction Velocity (SNCV) of the median and ulnar nerve in the upper limb and the sural nerve in the lower limb were recorded bilaterally in all the subjects as in Table 1. The Conduction Velocity (CV) is the speed of propagation of the action potential along a nerve. It is measured in $\mathrm{m} / \mathrm{sec}$. CV: Distance between stimulus and the recording electrode/onset latency.

All the data were entered in the MS excel spreadsheet and the statistical analysis was done using SPSS version 17.0. The data were expressed as mean \pm standard deviation. Descriptive tables were generated and student $t$ test was used to demonstrate the findings. $P$ value of less than 0.05 was considered to be statistically significant.

\begin{tabular}{|c|c|c|c|}
\hline Nerve & $\begin{array}{c}\text { Antidromic/ } \\
\text { Orthodromic }\end{array}$ & $\begin{array}{c}\text { Point of } \\
\text { Stimulation }\end{array}$ & $\begin{array}{c}\text { Point of } \\
\text { Recording }\end{array}$ \\
\hline Median & Antidromic & Wrist & $\begin{array}{c}\text { Index } \\
\text { Finger }\end{array}$ \\
\hline Ulnar & Antidromic & Wrist & $\begin{array}{c}\text { Little } \\
\text { Finger }\end{array}$ \\
\hline Sural & Antidromic & $\begin{array}{c}\text { At the junction of } \\
\text { the middle and } \\
\text { lower 1/3 of the } \\
\text { leg }\end{array}$ & Ankle \\
\hline \multicolumn{3}{|c|}{ Table 1: Details of Sensory Nerve Conduction } \\
Recordings
\end{tabular}

\begin{tabular}{|c|c|c|c|}
\hline Parameters & $\begin{array}{c}\text { Group I Subjects } \\
\text { with Iron- } \\
\text { Deficiency } \\
\text { Anaemia (n=40) } \\
\text { Mean } \pm \text { SD }\end{array}$ & $\begin{array}{c}\text { Group II } \\
\text { Controls } \\
(\mathbf{n}=\mathbf{3 0}) \\
\text { Mean } \pm \text { SD }\end{array}$ & P Value \\
\hline Age & $43.6 \pm 8.9$ & $38.4 \pm 11.7$ & 0.08 \\
\hline Height & $158 \pm 11$ & $161 \pm 8.8$ & 0.228 \\
\hline Weight & $60 \pm 10.9$ & $63.7 \pm 11.6$ & 0.576 \\
\hline BMI & $23.06 \pm 4.03$ & $24.01 \pm 4.24$ & 0.144 \\
\hline $\begin{array}{c}\text { Table 2: Comparison of Anthropometric Data between Subjects } \\
\text { with Iron-Deficiency Anaemia and Normal Subjects }\end{array}$ \\
\hline
\end{tabular}

SD: Standard Deviation; $\mathrm{P}<0.05$ is Statistically Significant

\begin{tabular}{|c|c|c|c|c|c|}
\hline \multicolumn{2}{|c|}{ Nerve } & $\begin{array}{c}\text { SNCV }(\mathrm{m} / \mathrm{s}) \\
\text { Iron- } \\
\text { Deficiency } \\
\text { Anaemia } \\
(\mathrm{n}=40) \\
\text { Mean } \pm \text { SD } \\
\end{array}$ & $\begin{array}{c}\text { SNCV }(\mathrm{m} / \mathrm{s}) \\
\text { Controls } \\
(\mathrm{n}=30) \\
\text { Mean } \pm \text { SD }\end{array}$ & $\begin{array}{c}\mathrm{T} \\
\text { Value }\end{array}$ & $\begin{array}{c}P \\
\text { Value }\end{array}$ \\
\hline \multirow{2}{*}{$\begin{array}{c}\text { Median } \\
\text { Nerve }\end{array}$} & Right & $47.16 \pm 7.60$ & $52.82 \pm 5.20$ & -2.5 & $0.01^{*}$ \\
\hline & Left & $48.8 \pm 7.04$ & $51.86 \pm 5.2$ & -1.63 & 0.11 \\
\hline \multirow{2}{*}{$\begin{array}{l}\text { Ulnar } \\
\text { Nerve }\end{array}$} & Right & $47.52 \pm 8.56$ & $52.21 \pm 6.27$ & -1.92 & 0.06 \\
\hline & Left & $46.53 \pm 8.23$ & $50.94 \pm 6.24$ & -1.79 & 0.07 \\
\hline \multirow{2}{*}{$\begin{array}{c}\text { Sural } \\
\text { Nerve }\end{array}$} & Right & $43.64 \pm 5.4$ & $47.74 \pm 3.87$ & -2.62 & $0.01^{*}$ \\
\hline & Left & $44.18 \pm 5.29$ & $47.75 \pm 2.87$ & -2.27 & $0.03^{*}$ \\
\hline \multicolumn{6}{|c|}{$\begin{array}{c}\text { Table 3: Comparison of Sensory Nerve Conduction } \\
\text { Velocity between Subjects with Iron-Deficiency Anaemia } \\
\text { and Normal Subjects }\end{array}$} \\
\hline
\end{tabular}

SD: Standard Deviation, *: Statistically Significant, SNCV: Sensory Nerve Conduction Velocity.

\section{RESULTS}

Table 2 compares the anthropometric parameters between subjects with iron-deficiency anaemia $(n=40)$ and normal subjects $(n=30)$, which shows that there is no significant difference between the two groups. Table 3 compares the Sensory Nerve Conduction Velocity (SNCV) between subjects with iron-deficiency anaemia and normal subjects and shows a statistically significant decrease in the sensory nerve conduction velocities of right median nerve and bilateral sural nerves when compared to the controls.

\section{DISCUSSION}

In this study, we compared the sensory nerve conduction velocity of median, ulnar, and the sural nerves between 40 subjects with iron-deficiency anaemia and 30 controls. The comparison of age, height, and BMI of controls, and subjects with iron-deficiency anaemia did not reveal any significant difference. Table 2 shows that both the groups were comparable. As shown in Table 3, the sensory nerve conduction velocity in median, ulnar, and sural nerves was decreased in the subjects with iron-deficiency anaemia than the controls, but the decrease in the conduction velocity of right median and bilateral sural nerves were found to be statistically significant. The results of the study are consistent with the study by Y Degirmenci et al[5] and the study by Kabakus $\mathrm{N}$ et al,[6] Degirmenci $\mathrm{Y}$ et al[5] performed nerve conduction study in 52 patients with newly-diagnosed irondeficiency anaemia and 38 healthy controls and found that bilateral median nerve sensory conduction values and sural nerve sensory nerve conduction values are significantly reduced in patients with iron-deficiency anaemia and Kabakus et al recorded the nerve conduction velocity in the median and posterior tibial nerve of 18 individuals with iron-deficiency anaemia compared with 12 healthy controls and found that the nerve conduction velocity was reduced in individuals with iron-deficiency anaemia.[6] However, these results were contradicted by Akyol A et al[7] who concluded that irondeficiency anaemia does not cause significant electrophysiological changes in peripheral nerves.

In our study, the Sensory Nerve Conduction Velocity (SNCV) were significantly decreased in the median and sural nerves, which shows the development of peripheral neuropathy in iron-deficiency anaemia. As various metabolic and enzymatic processes such mitochondrial electron transport, synthesis, and degradation of neurotransmitters and the synthesis of proteins depends on iron, iron deficiency may have various effects on neurological functions. ${ }^{[8]}$ Nerves could also be affected by the chronic ischaemia process of irondeficiency anaemia..99] Galan $\mathrm{P}$ et al[10] and $\mathrm{Yu}$ et al[11] did experiments in rats and found that iron deficiency leads to reduced levels of myelination and a shortage of myelin proteins and lipids. Iron deficiency causes disruption in myelination, neurotransmitter neurochemistry, and neuronal energetics in neural functioning.[12]

\section{CONCLUSION}

We found that the sensory nerve conduction velocity was reduced in subjects with iron-deficiency anaemia that confirms the involvement of peripheral nerves in irondeficiency anaemia. Our study is preliminary and the benefits of iron supplementation in such neuropathy can be studied in large randomised trial. 


\section{REFERENCES}

1. World Health Organisation. Focusing on anaemia: towards an integrated approach for effective anaemia control. Joint statement by the WHO and the United Nations children's fund. Geneva 2004. http://whqlibdoc.who.int/hq/2004/anaemiastatement. pdf

2. World Health Organisation. Iron-deficiency anaemia: assessment, prevention, and control-a guide for program managers. Geneva, Switzerland: WHO. WHO/NHD/01.3, 2001.

3. Lozoff B, Wolf AW, Jimenez E. Iron-deficiency anaemia and infant development: effects of extended oral iron therapy. J Paediatr 1996;129(3):382-9.

4. Lozoff B, Wolf AW, Urrutia JJ, et al. Abnormal behaviour and low developmental test scores in iron-deficient anaemic infants. J Dev Behav Paediatr 1985;6(2):69-75.

5. Degirmenci Y, Kececi H. Electrophysiological changes in iron-deficiency anaemia. Neurol Croat 2011;60(1):3-10.

6. Kabakus N, Ayar A, Yoldas TK, et al. Reversal of irondeficiency anaemia-induced peripheral neuropathy by iron treatment in children with iron-deficiency anaemia. J Trop Paediatr 2002;48(4):204-9.
7. Akyol A, Kiylioglu N, Kadikoylu G, et al. Iron-deficiency anaemia and restless legs syndrome: is there an electrophysiological abnormality? Clin Neurol Neurosurg 2003;106(1):23-7.

8. Schwartz E. Iron-deficiency anaemia. In: Behrman RE, Kliegman MR, Arvin MA. eds. Textbook of paediatrics. 15 th edn. Philadelphia: WB Saunders 1996:1387-9.

9. Brett EM. Vascular disorders of the nervous system in childhood. In: Brett EM. ed. Paediatric Neurology. $3^{\text {rd }}$ edn. New York: Churchill Livingstone 1997:579.

10. Yu GS, Steinkirchner TM, Rao GA, et al. Effect of prenatal iron deficiency on myelination in rat pups. The American Journal of Pathology 1986;125(3):620-4.

11. Galan P, Hercberg S, Touitou Y. The activity of tissue enzymes in iron deficient rat and man: an overview. Comp Biochem Physiol B 1984;77(4):647-53.

12. Beard JL, Connor JR. Iron status and neural functioning. Annu Rev Nutr 2003;23(1):41-58. 